\title{
PENERAPAN AJARAN TRI HITA KARANA DALAM PENYUSUNAN $A W I G-A W I G$ SEKAA TERUNA TAMAN SARI DI BANJAR LANTANG BEJUH DESA ADAT SESETAN
}

\author{
I Nyoman Alit Putrawan', I Made Adi Widnyana', I Made Suastika Ekasana, \\ Desyanti Suka Asih K.Tus ${ }^{4}$, I Gusti Ayu Jatiana Manik Wedanti ${ }^{5}$ \\ Universitas Hindu Negeri I Gusti Bagus Sugriwa Denpasar \\ 2adiwidnyana.ihdn@gmail.com
}

\begin{abstract}
Customary law in Bali is a basis or guideline in carrying out rights and obligations in an indigenous organization, including Sekaa Teruna. The form of customary law in Bali is Awig-Awig, in terms of the preparation of Awig-Awig the concept of wisdom in the community is often adopted as part of the existing peculiarities. The purpose of this writing is for to show that the concept of Tri Hita Karana is able to be synergized in the process of preparing AwigAwig and become an important part in explaining the relationship of rights and obligations krama. From the study carried out the concept of customary legal order dibali exist in various forms such as awig, awig, perarem, eka eli kita, and others. The concept of Tri Hita Karana is often used in linking the rights and obligations of Sekaa members in the fields of parhyangan, pawongan and palemahan. In the preparation of Awig-Awig Sekaa Teruna Taman Sari is carried out synergy by using Tri Hita Karana as a foothold in describing self-sufficiency in three areas of life.
\end{abstract}

Keywords: Adat Law, Awig-Awig, Tri Hita Karana, Sekaa Teruna

\begin{abstract}
Abstrak
Hukum adat di Bali merupakan suatu dasar atau pedoman dalam melaksanakan hak dan kewajiban dalam suatu organisasi adat, tidak terkecuali Sekaa Teruna. Adapun bentuk dari hukum adat di Bali salah satunya adalah Awig-Awig, dalam hal penyusunan Awig-Awig konsep kearifan yang ada di masyarakat sering diadadorpsi sebagai bagian dari kekhasan yang ada. Tujuan dari penulisan ini adalah untuk menunjukkan bahwa konsep Tri Hita Karana mampu disinergikan di dalam proses penyusunan Awig-Awig dan menjadi bagian penting di dalam menjelaskan hubungan hak dan kewajiban krama. Dari pengkajian yang dilakukan konsep tatanan hukum adat di Bali ada dalam berbagai bentuk seperti awig, awig, perarem, eka eli kita, dan lainnya. Konsep Tri Hita Karana sering digunakan dalam mengkaitkan hubungan hak dan kewajiban anggota Sekaa dalam bidang parhyangan, pawongan dan palemahan. Di dalam penyusunan Awig-Awig Sekaa Teruna Taman Sari dilakukan sinergitas dengan menggunakan Tri Hita Karana sebagai pijakan dalam menjabarkan swadarmaning krama di dalam tiga bidang kehidupan.
\end{abstract}

Kata Kunci: Hukum Adat, Awig-Awig, Tri Hita Karana, Sekaa Teruna 


\section{Pendahuluan}

Hukum adat senantiasa menjadi bagian dari pembangunan hukum nasional. Sistemsistem hukum adat melengkapi pelaksanaan hukum di Indonesia, sebagai konsekuensi dari heterogenitas masyarakat di Indonesia yang terdiri dari berbagai daerah-daerah dengan karakteristik masyarakatnya yang khas (Kusuma-Atmadja, 2012). Bali merupakan salah satu daerah di Indonesia yang memiliki karakteristik tersendiri dengan adat, budaya dan agama yang tumbuh saling menguatkan. Tatanan kehidupan masyarakat Bali dilandasi oleh keberadaan hukum adat dari masa dahulu (Purnama \& Dewi, 2019).

Hukum adat di Bali merupakan suatu dasar atau pedoman dalam melaksanakan hak dan kewajiban oleh masyarakat Bali dalam ikatan organisasi adat. Organsasi adat di Bali secara struktur terbentuk dari kelompok-kelompok masyarakat berdasarkan persamaan tujuan yang sering diistilahkan dengan Sekaa (Wayan P, Windia, 2016). Tiap-tiap sekaa ini memiliki pedoman atau hukum adat tersendiri, tidak terkecuali Sekaa Teruna, yang merupakan salah satu organisasi tradisional di Bali yang anggotanya terdiri dari para yowana atau muda-mudi yang belum menikah atau belum memasukki masa grahasta asrama (Kumala Dewi et al., 2018). Dalam menjalankan roda organisasi Sekaa Teruna dibutuhkan suatu anggaran dasar dan aturan rumah tangga yang mengatur tentang keberadaan Sekaa termasuk hak serta kewajiban anggota Sekaa Teruna tersebut, sehingga eksestensi dari Sekaa Teruna tersebut dapat dipertahankan dengan adanya suatu pedoman serta dasar tuntunan dalam berprilaku yang dihormati oleh seluruh anggota Sekaa Teruna.

Awig-Awig tidak dapat dilepaskan dari sima dresta yang berlaku dalam suatu wilayah adat, sehingga keberadaan Awig-Awig setiap daerah tidaklah sama (Sumarjo, 2018). Penyusunan Awig-Awig haruslah melibatkan berbagai komponen dalam masyarakat baik tokoh agama, tokoh adat, para pinisepuh, dan tentunya kalangan akademisi untuk dapat melahirkan suatu aturan adat yang tentunya tidak bertentangan dengan keberadaan hukum nasional kita. Sehingga dengan memperhatikan hal-hal tersebut kedudukan hukum adat akan semakin kuat dan tidak tergerus oleh kemajuan jaman dengan melakukan tinjauan atau perevisian secara berkala, mengikuti perubahan masa yang terjadi.

Khusus di Banjar Lantang Bejuh terdapat Organisasi Sekaa Teruna yang usianya sudah 50 tahun (per-tahun 2020). Dalam menjalankan organisasi selama ini mereka hanya menggunakan sima dresta yang belum tersurat atau tertulis, sehingga dalam melaksanakan kegiatan Sekaa hanya menggunakan amanah Klian Sekaa (Pimpinan Sekaa) sebagai hukum yang harus dituruti setiap anggota. Adanya amanah atau aturan lisan inilah yang menimbulkan adanya ketidakpastian hukum dalam menjalankan roda organisasi, karena sifatnya hanya menunggu keputusan dari Klian Sekaa ketika menghadapi suatu persoalan atau hal yang akan diputuskan. Namun seiring perkembangan tuntutan jaman yang membatasi waktu serta meningkatkan kesibukan para anggota dalam hal mencari nafkah serta kegiatan di luar organisasi tentu tidak bisa menjalankan amanah tersebut secara maksimal, sehingga perlu dilakukan penyusunan suatu pedoman atau aturan dasar untuk anggota yang disesuaikan dengan perkembangan jaman sekarang, sehingga seluruh anggota Sekaa Teruna dapat menghormati dan mengikuti aturan tertulis tersebut. Namun konsep Awig-Awig Sekaa Teruna yang hendak disusun harus disinergikan dengan keberadaan Awig-Awig Banjar Adat serta Awig-Awig Desa Adat Sesetan, serta nilai-nilai adi luhung yang memang telah ada di Banjar Lantang Bejuh Sesetan, sehingga tidak saling tumpang tindih serta mengabaikan dasar-dasar kearifan yang ada. Konsep kearifan lokal yang umumnya diterapkan dalam penyusunan AwigAwig salah satunya adalah konsep Tri Hita Karana (Astiti et al., 2011). Konsep Tri Hita Karana adalah konsep yang mampu menyelaraskan kehidupan manusia dengan Tuhan (Parhyangan), dengan manusia (Pawongan), serta alam lingkungan sekitarnya (Palemahan) (Runa, 2012). Sehingga di dalam Awig-Awig, konsep ini dimasukkan untuk membuat pengaturan kehidupan atau kegiatan di ketiga bidang utamanya menjadi lebih jelas dan terarah. Karena pada dasarnya tata kehidupan masyarakat di Bali memang berlandaskan ketiga konsep 
Tri Hita Karana tersebut. Begitupula dalam penyusunan Awig-Awig untuk Sekaa Teruna Taman Sari di Banjar Lantang Bejuh juga menggunakan konsep Tri Hita Karana dalam pelaksanaan kewajiban anggota Sekaanya.

Untuk itu dalam penulisan ini akan dilihat sejauhmana tatanan hukum adat di Bali, penjelasan ajaran Tri Hita Karana yang secara umum yang digunakan dalam sistematika AwigAwig, serta penerapan ajaran Tri Hita Karana di dalam penyusunan Awig-Awig Sekaa Teruna Taman Sari. Tujuan dari penulisan ini adalah untuk menunjukkan bahwa ajaran Tri Hita Karana mampu diterapkan melalui sinergitas di dalam proses penyusunan Awig-Awig dan menjadi bagian penting di dalam hubungan menjelaskan hak dan kewajiban krama.

\section{Metode}

Metode yang digunakan dalam penyusunan tulisan ini menggunakan jenis penulisan hukum normative, yakni penulisan yang menggunakan bahan-bahan hukum dalam pengkajiannya (Diantha et al., 2018). Penulisan ini menggunakan pendekatan studi kepustakaan (bahan-bahan pustaka atau literatur) dan studi perbandingan (Ibrahim, 2005). Studi kepustakaan dilakukan dengan mengkaji literatur serta sumber-sumber hukum adat berupa Awig-Awig maupun perarem, dan konsep kearifan Tri Hita Karana serta dilakukan pendekatan studi perbandingan dengan melihat beberapa ketentuan Awig-Awig Sekaa Teruna yang berlaku di daerah lainnya untuk dibandingkan dan diadorpsi jika sesuai dengan kebutuhan yang diinginkan serta relevan diterapkan oleh organisasi atau Sekaa Teruna di Banjar Lantang Bejuh Desa Adat Sesetan.

\section{Hasil dan Pembahasan}

Dari pendahuluan di atas maka dalam tulisan ini akan membahas mengenai tatanan hukum adat di Bali, ajaran Tri Hita Karana, serta penerapan Tri Hita Karana di dalam penyusunan Awig-Awig Sekaa Teruna Taman Sari Banjar Lantang Bejuh Desa Adat Sesetan.

\section{Tatanan Hukum Adat di Bali}

Seperti diketahui, setiap Desa adat di Bali memiliki tatanan hukum sosial adat berupa Awig-Awig yang berbeda satu sama lainnya (Sudiatmaka \& Apsari Hadi, 2018). Awig-Awig merupakan tata dalam hidup bermasyarakat. Masyarakat sendiri ditandai oleh beberapa ciri, seperti adanya interaksi, ikatan, pola tingkah laku yang khas dalam semua aspek kehidupan yang bersifat mantap dan kontinyu, serta adanya rasa identitas terhadap kelompok dimana individu yang bersangkutan menjadi anggotanya (Rahman \& Selviyanti, 2018). Dalam kehidupan bermasyarakat, manusia akan senantiasa berhadapan dengan kekuatan-kekuatan manusia lainnya, sehingga diperlukan adanya norma-norma dan aturan-aturan yang menentukan tindakan mana yang boleh dan mana yang tidak boleh dilakukan. Awig-Awig yang dijadikan pegangan oleh prajuru desa adat dalam mengemban kewajibannya, dibuat sesuai dengan situasi dan kondisi objektif masing-masing desa adat. Hal ini menyebabkan adanya perbedaan antar Awig-Awig desa adat yang satu dengan yang lainnya walaupun secara geografis letaknya berdekatan. Perbedaan ini dianggap normal dan lumrah sesuai dengan asas desa mawacara (Wibawa et al., 2020). Awig-Awig di Bali dapat dibentuk oleh organisasi Desa adat dan/atau Banjar Adat. Jika melihat dari sejarah awig-awig yang merupakan aturan atau pedoman dasar untuk menjalankan kewajiban serta hak dibuat oleh organisasi tradisional yang disebut sekaa, sebagai contoh diawali oleh subak di Bali (Muderana, 1998). Olah karenanya sampai saat ini sekaa-sekaa yang ada di lingkup bebanjaranpun dapat menyusun awig-awig, namun tidak dapat lepas dari awig-awig Desa adat maupun banjar adat di atasnya yang telah disahkan oleh dinas terkait di Provinsi Bali (Mahadewi et al., 2020).

Dalam pasal 1 angka (29) Peraturan Daerah Provinsi Bali Nomor 4 Tahun 2019 tentang Desa Adat menyebutkan, Awig-Awig adalah aturan yang dibuat oleh Desa Adat dan/atau Banjar 
Adat yang berlaku bagi Krama Desa Adat, Krama Tamiu, dan Tamiu. Dalam Bab IV tentang Awig-Awig, Pararem, dan Peraturan lain Desa Adat, pada Pasal 13 mengatur:

a. Setiap Desa Adat memiliki Awig-Awig.

b. Awig-Awig sebagaimana dimaksud pada ayat (1) terdiri atas:

1) Awig-Awig tersurat; dan

2) Awig-Awig yang belum tersurat.

c. Awig-Awig tersurat dan yang belum tersurat mempunyai kekuatan hukum yang sama.

d. Setiap Desa Adat berkewajiban menyuratkan Awig-Awig.

e. Ketentuan mengenai Tata cara penyuratan Awig-Awig sebagaimana dimaksud pada ayat (4) diatur lebih lanjut dalam Peraturan Gubernur.

Dalam Pasal 16 disebutkan lebih lanjut bahwa:

a. Awig-Awig Desa Adat dibuat dan disahkan dalam Paruman Desa Adat.

b. Awig-Awig sebagaimana dimaksud pada ayat (1) berlaku sejak kasobyahang/diumumkan dalam Paruman Desa Adat (Sastra Wibawa et al., 2020).

Substansi Awig-Awig secara garis besarnya berisi Murdha Citta, Pamikukuh, Petitis, asas-asas, norma atau kaidah, dan sanksi (Sudiatmaka \& Apsari Hadi, 2018). Aturan pelaksanaan yang lebih rinci dituangkan dalam bentuk keputusan rapat desa yang disebut perarem. Perarem memiliki kekuatan mengikat yang secara substansi bisa dikelompokkan menjadi tiga, perarem penyahcah awig, perarem ngele/lepas, dan perarem penepas wicara (Perbawa, 2020). Perarem penyahcah awig artinya aturan pelaksanaan dari Awig-Awig tertulis yang sudah ada. Perarem Pangele berupa keputusan paruman yang merupakan aturan hukum baru yang tidak ada landasannya dalam Awig-Awig tertulis. Hal ini biasanya dipakai untuk mengakomodir kebutuhan hukum baru untuk mengikuti perkembangan masyarakat. Perarem penepas wicara merupakan keputusan paruman mengenai suatu wicara (perkara) yang berupa persoalan hukum seperti sengketa maupun pelanggaran hukum (Made Adi Widnyana \& Putu Tagel, 2019).

\section{Ajaran Tri Hita Karana Di Bali}

Secara leksikal Tri Hita Karana berarti tiga penyebab kesejahteraan. $($ Tri $=$ tiga, Hita $=$ sejahtera, Karana = penyebab). Pada hakikatnya Tri Hita Karana mengandung pengertian tiga penyebab kesejahteraan itu bersumber pada keharmonisan hubungan antara:

a. Parhyangan, yang berarti hubungan Manusia dengan Tuhannya.

b. Palemahan, yang berarti hubungan Manusia dengan alam lingkungannya, dan

c. Pawongan, yang berarti hubungan Manusia dengan sesamanya (Paramajaya, 2018).

Istilah Tri Hita Karana pertama kali muncul pada tanggal 11 Nopember 1966, pada waktu diselenggarakan Konferensi Daerah 1 Badan Perjuangan Umat Hindu Bali bertempat di Perguruan Dwijendra Denpasar (Nopitasari \& Putrawan, 2013). Konferensi tersebut diadakan berlandaskan kesadaran umat Hindu akan dharmanya untuk berperan serta dalam pembangunan bangsa menuju masyarakat sejahtera, adil dan makmur berdasarkan Pancasila. Kemudian istilah Tri Hita Karana ini berkembang, meluas, dan memasyarakat. Unsur- unsur Tri Hita Karana ini jika kita dalami dalam ajaran agama hindu terdapat di dalam kitab suci Bagawad Gita (III.10) (Bagus, 1967), yang berbunyi sebagai berikut:

Sahayajnah prajah sristwa pura waca prajapatih anena prasawisya dhiwan esa wo'stiwistah kamadhuk

Terjemahannya:

Pada jaman dahulu Prajapati menciptakan manusia dengan Yadnya dan bersabda: dengan ini engkau akan berkembang dan akan menjadi kamadhuk dari keinginanmu.

Dalam sloka Bhagavad-Gita (Penerjemah Tim, 2006) tersebut ada nampak unsur yang saling ber-Yadnya untuk mendapatkan kebahagian yaitu terdiri dari: Prajapati = Tuhan Yang Maha Esa, Praja = Manusia, yang kemudian dapat dikembangkan mengandung tiga unsur: a. Sanghyang Jagatkarana. 


\section{b. Bhuana. \\ c. Manusa}

Penjabaran Tri Hita Karana dalam kehidupan umat Hindu diistilahkan dalam bentuk tiga hubungan sebagai berikut

a. Parhyangan, hubungan antara manusia dengan Tuhannya yang diwujudkan dengan dewa yadnya.

b. Palemahan, hubungan manusia dengan alam lingkungannya yang diwujudkan dengan bhuta yadnya.

c. Pawongan, hubungan antara manusia dengan sesamanya diwujudkan dengan pitra, resi, manusia yadnya.

\section{Penerapan Tri Hita Karana dalam Awig-Awig Sekaa Teruna Taman Sari}

Di dalam Awig-Awig penerapan Tri Hita Karana ditunjukkan dalam sinergitas konsep Tri Hita Karana dapat dilihat sistematika yang dianut dalam penyusunan awig awig secara umum seperti yang disampaikan oleh Prof Windia meliputi:

a. Murdha Citta

b. Aran Lan Wewidangan Desa

c. Petitis Lan Pemikukuh

d. Sukerta Tata Agama

e. Sukerta Tata Pawongan

f. Sukerta Tata Palemahan

g. Wicara Lan Pamidanda

h. Nguwah-nguwuhin Awig-Awig

i. Samapta (Wayan P, Windia, 2016)

Murdha Citta adalah pembuka dalam suatu Awig-Awig yang dapat berisi raya syukur bahwa penyusunan Awig-Awig telah berhasil dilaksanakan, berisi alasan dan tujuan dilakukan penyusunan Awig-Awig serta pengantar lainnya.

Aran lan wewidangan adalah Nama atau identitas dari Sekaa atau organisasi yang menyusun Awig-Awig serta batasan-batasan wilayah dari keberadaan Sekaa atau organisasi tersebut. Dalam bagian ini juga dapat diisikan klasifikasi Sekaa maupun keanggotannya.

Petitis lan Pamikukuh adalah Dasar-dasar, asas-asas, serta norma atau kaidah yang digunakan dalam penyusunan Awig-Awig, baik itu merupakan dasar hukum dari aturan nasional mapun dasar hukum dari aturan adat di atasnya. Dasar yang lain adalah ketentuan tidak tertulis atau kearifan yang menjadi pokok bagi keberlangsungan Sekaa di suatu daerah. Dalam hal ini juga. Bagian inti dari ajaran Tri Hita Karana dalam awig-awig terlihat pada bagian sukerta tata agama, sukerta tata pawongan dan sukerta tata palemahan.

Sukerta tata Agama atau Sukerta tata parhyangan, adalah konsep hak dan kewajiban yang dilakukan oleh krama dalam hal mengatur hubungan antara krama dengan keberadaan tempat-tempat suci atau pelaksanaan kehidupan keagamaan di suatu wilayah. Misalnya mengenai bagaimana hak dan kewajiban krama terhadap keberadaan khayangan tiga, pura banjar atau begawan penyarikan atau tempat suci lainnya di wilayah setempat.

Sukerta tata Pawongan, sesungguhnya adalah inti dari pengaturan Awig-Awig yang mencakup tentang hak dan kewajiban yang ditimbulkan dari hubungan antara krama dengan krama yang lainnya. Hubungan ini dapat menimbulkan kebaikan atau justru pertentangan yang dapat diatur sehingga tetap terkendali.

Sukerta tata Palemahan, adalah bagian yang berisi hak dan kewajiban krama dalam hubungannya dengan lingkungan atau alam. Hal ini dapat berupa pengaturan tentang keamanan wilayah, ketertiban, serta kenyamanan wilayah yang dapat dilakukan dengan upaya -upaya tertentu yang diatur di dalam Awig-Awig.

Wicara lan Pamidanda, adalah sanksi atau hukuman yang disusun berdasarkan pada pelanggaran atau penyimpangan terhadap ketentuan yang diatur di dalam Awig-Awig. Sanksi 
ini dapat diklasifikasikan dalam sanksi ringan, sedang ataupun berat, atau dilihat dari sifatnya dapat berupa sanksi materi atau sanksi moral.

Nguwah-Nguwehin Awig-Awig, adalah bagian yang berupa penyempurnaan atau tambahan terhadap ketentuan yang belum diatur di atasnya, atau bagian penjelasan, serta dapat berisi kalimat akan disempurnakan oleh ketentuan hukum yang lainnya.

Samapta adalah bagian penutup dari bagian Awig-Awig yang berisi tentang kapan disahkan dan diberlakukannya Awig-Awig, berisi tentang para pihak yang menandatangani, masa waktu awig, serta pihak-pihak yang diikat dengan Awig-Awig tersebut.

Di dalam Awig-Awig Sekaa Teruna Taman Sari yang disusun, keberadaan ajaran Tri Hita Karana terlihat dalam bagian Swa Dharmaning Sekaa Truna-Truni Taman Sari, tepatnya di dalam Pawos Sia Awig-Awig yang berbunyi:

Swa Dharmaning warga Sekaa Truna-Truni luire :

Ha .Ring Tata Parhyangan;

Siki. patut nyarengin pemargin subhakti warga banjar ring genah parhyangan lan pelawatan Ida Bhatara sane wenten ring Banjar Lantang Bejuh, Khayangan Tiga Desa Adat Sesetan, taler Pura Lianan sane Mapaiketan

Kalih. mingsinggihin kewentenan pemangku Banjar lan Kyangan Tiga sami.

Terjemahannya:

Bahwa dalam hal menjalankan hubungannya dengan Tuhan, anggota sekaa teruna subhakti dan taat sebagai anggota banjar yang menjunjung keberadaan simbul-simbul keagamaan yang ada di Banjar Lantang Bejuh dan Khayangan Tiga di Sesetan. Serta dalam hal ini sekaa teruna juga menghormati keberadaan mangku selaku pemuka agama.

Na. Ring Tata Pawongan;

Siki. Patut mikukuhang paiketan pantaraning warga Sekaa, pantaraning warga banjar, lan warga desa adat taler ngawangiang parinama Sekaa Truna-Truni Taman Sari.

Kalih. Wenang ngamiletin paruman nangken sasih nangken paruman nem sasihan Tiga. Para pamilet paruman kengin ngamedalang pikayun, ngungguhang usul-usul nincapang kawerdian Sekaa Truna-Truni Taman Sari.

Pat. Nawur urunan sasihan.

a. Krama anyar sane wau dados warga Sekaa patut nawur panutug kas.

b. Krama Pengampel keni jinah Pamogpog sane akehnyane manut pemutus paruman Sekaa

c. Makasami warga Sekaa Truna-Truni patut nyungkemin Awig-Awig druene lan pamutus paruman utawi sangkep Sekaa.

Lima. Patut ngemargiang pasuka-dukaan pantaraning warga Sekaa Truna - Truni minakadi: pawiwahan, kasungkanan, kalayusekar manut pituduh prajuru Sekaa TrunaTruni.

Terjemahannya:

Bahwa dalam menjalankan hubungan antar sesama dan anggota Sekaa teruna, mereka mengutamakan persatuan dan kesatuan anggota antar banjar maupun antar Desa Sesetan, selain itu anggota sekaa juga memiliki kewajiban dalam mengikuti rapat dan memiliki hak suara untuk menyampaikan pendapat, serta memiliki tugas dalam membayar iuran bersama, serta menjalankan kegiatan suka-duka sebagai cerminan rasa memiliki dan tenggang rasa.

Ca. Ring Tata Palemahan: Patut ngemargiang pareresikan ring wewidangan Banjar Lantang Bejuh, najuk taru, utawi parikrama siosan manut pituduh prajuru Sekaa, prajuru banjar adat lan dinas.

Terjemahannya: 
Bahwa di dalam menjalankan hubungan dengan alam sekitar, anggota sekaa memperhatikan keasrian lingkungan, kebersihan, sesuai dengan arahan dan petunjuk Pemerintah.

Dalam bagian swadarmaning (kewajiban) anggota sekaa teruna di atas terlihat bahwa penerapan ajaran Tri Hita Karana menjadi bagian yang tidak dapat dipisahkan dalam kehidupan sekaa teruna yang di atur di dalam menjalankan kegiatan religius, sosial, dan budaya.

\section{Kesimpulan}

Dari uraian di atas dapat disimpulkan hal sebagai berikut:

1. Tatanan hukum adat di Bali dapat berupa bentuk Awig-Awig, perarem, eka eli kita, ataupun bentuk lainnya baik yang tersurat maupun tidak, yang menjadi dasar dan pedoman serta keyakinan masyarakat dalam menjalankan kehidupan.

2. Dalam ajaran agama Hindu disebutkan bahwa ajaran Tri Hita Karana, adalah tiga penyebab kesejahteraan. Ajaran Tri Hita Karana meliputi tiga hal yakni: Parhyangan, yang berarti hubungan Manusia dengan Tuhannya. Palemahan, yang berarti hubungan Manusia dengan alam lingkungannya, dan Pawongan, yang berarti hubungan Manusia dengan sesamanya.

3. Dalam penyusunan Awig-Awig Sekaa Teruna Taman Sari banjar Lantang Bejuh, penerapan ajaran Tri Hita Karana sangat penting. Hal ini ditunjukkan dengan menjadikan ajaran Tri Hita Karana sebagai pokok atau bantangan dalam sistematika penyusunan Awig-Awig. Hal ini terlihat dalam bagian pawos yang membahas tentang hak dan kewajiban atau swadarmaning anggota Sekaa, yang meliputi sukerta tata agama, sukerta tata pawongan, dan sukerta tata palemahan.

\section{Daftar Pustaka}

Astiti, T. I. P., Windia, W., Sudantra, I. K., Wijaatmaja, I. G. M., \& Dewi, A. A. I. A. A. (2011). Implementasi Ajaran Tri Hita Karana Dalam Awig-awig. The Exellence Research, 2007.

Bagus, I. (1967). Bhagawad Ghita, Alih Bahasa. PHDIP.

Diantha, P., Dharmawan, N. K. S., \& Artha, I. G. (2018). Metode Penelitian Hukum dan Penulisan Disertasi (I. G. Ag. Kurniawan (ed.)). Swasta Nulus.

Ibrahim, J. (2005). Teori \& Metodelogi Penelitian Hukum Normatif. Bayu Media.

Kumala Dewi, N. K. R., Vijayantera, I. W. A., \& Saraswati, P. S. (2018). Fungsi Hukum Adat Dalam Penguatan Peran Sekaa Teruna Di Desa Adat Kuta Untuk Perlindungan Tradisi Medelokan Penganten. Jurnal Komunikasi Hukum (JKH), 4(1). https://doi.org/10.23887/jkh.v4i1.13661

Kusuma-atmadja, M. (2012). Mochtar Kusuma-Atmadja Dan Teori Hukum Pembangunan Eksistensi dan Implikasi (Shidarta (ed.)). Epistema Institute.

Made Adi Widnyana, I., \& Putu Tagel, D. (2019). Penerapan Sanksi Adat Dedosan Dalam Awig-Awig Banjar Pegok Desa Adat Sesetan. In Vyavahara Duta: Vol. XIV (Issue 2).

Mahadewi, I. G. A. M., Sukadana, I. K., \& Suryani, L. P. (2020). Pengesahan Awig-Awig Desa Adat berdasarkan Peraturan Daerah Nomor 4 Tahun 2019. Jurnal Konstruksi Hukum, 1(1). https://doi.org/10.22225/jkh.1.1.2155.187-191

Muderana, N. P. (1998). Eksistensi Organisasi Subak Di Bali. Perspektif, 3(3). https://doi.org/10.30742/perspektif.v3i3.218

Nopitasari, N. P. I., \& Putrawan, S. (2013). Konsep Tri Hita Karana Dalam Subak. E-Jurnal Ilmu Hukum Kerta Desa, I.

Paramajaya, I. P. G. (2018). Implementasi Konsep Tri Hita Karana Dalam Perspektif Kehidupan Global : Berpikir Global Berperilaku Lokal. Purwadita, 2(2).

Penerjemah Tim. (2006). Bhagawad Gita Menurut Aslinya. Hanuman Sakti. 
Perbawa, S. L. P. (2020). Implementasi Kebijakan Pemerintah Melalui Perarem Desa Adat Dalam Penanganan Covid 19. Percepatan Penangan Covid-19 Berbasis Adat Di Indonesia.

Purnama, D. G. A. S. Y., \& Dewi, A. A. I. A. A. (2019). Desa adat Dalam Pengelolaan Tanah Adat Bali Berbasis Kebijakan Daerah. Acta Comitas. https://doi.org/10.24843/ac.2019.v04.i02.p16

Rahman, B., \& Selviyanti, E. (2018). Studi Literatur: Peran Stratifikasi Sosial Masyarakat Dalam Pembentukan Pola Permukiman. Jurnal Planologi, 15(2). https://doi.org/10.30659/jpsa.v15i2.3525

Runa, I. (2012). Pembangunan Berkelanjutan Berdasarkan Konsep Tri Hita Karana untuk Kegiatan Ekowisata. JURNAL KAJIAN BALI (JOURNAL OF BALI STUDIES), 2(1).

Sastra Wibawa, I. P., Gelgel, I. P., \& Martha, I. W. (2020). Tata Cara Penyuratan Dan Pendaftaran Awig-awig Desa Adat di Bali (Dari Desa Mawacara ke Bali Mawacara). Mudra Jurnal Seni Budaya, 35(3). https://doi.org/10.31091/mudra.v35i3.1103

Sudiatmaka, K., \& Apsari Hadi, I. G. A. (2018). Penyuratan Awig-Awig Desa Pakraman. Jurnal Komunikasi Hukum (JKH), 4(1). https://doi.org/10.23887/jkh.v4i1.13659

Sumarjo. (2018). Eksistensi Awig-Awig dalam Menjaga Harmonisasi. Habitus: Jurnal Pendidikan Sosiologi, Dan Antropologi, 2.

Wayan P, Windia, K. S. (2016). Pengantar Hukum Adat Bali. In Cetakan kedua, Swasta Nulus bekerjasama dengan BAli Shanti.

Wibawa, I. P. S., Martha, I. W., \& Diana, I. K. D. (2020). Menakar Kewenangan Dan Tata Hubungan Kelembagaan Antara Majelis Desa Adat Dengan Desa Adat Di Bali. Vidya Wertta: Media Komunikasi Universitas Hindu Indonesia, 3(1). https://doi.org/10.32795/vw.v3i1.671 